\title{
Synthesis, Molecular Structure and Spectroscopic, Electrochemical and Magnetic Properties of a New Dinuclear Iron Complex Containing $\mu$-Sulfate-di- $\mu$-alkoxo Bridges. Evaluating the Influence of the Sulfate Bridge on the Physicochemical Properties of the Di- $\mu$-alkoxo-diiron Unit
}

\author{
Adolfo Horn Jr., ${ }^{*, a}$ Ivo Vencato, ${ }^{e}$ Adailton J. Bortoluzzi, ${ }^{b}$ Valderes Drago, ${ }^{c}$ \\ Miguel A. Novakd and Ademir Neves ${ }^{b}$ \\ ${ }^{a}$ Laboratório de Ciências Químicas, Universidade Estadual do Norte Fluminense, 28013-602 \\ Campos dos Goytacazes - RJ, Brazil \\ ${ }^{b}$ Departamento de Química, Universidade Federal de Santa Catarina, 88040-900 Florianópolis - SC, Brazil \\ ${ }^{c}$ Departamento de Física, Universidade Federal de Santa Catarina, 88040-900 Florianópolis - SC, Brazil \\ ${ }^{d}$ Instituto de Física, Universidade Federal do Rio de Janeiro, 21945-970 Rio de Janeiro -RJ, Brazil \\ ${ }^{e}$ Instituto de Física, Universidade Federal de Goiás, 74001-970 Goiânia - GO, Brazil
}

\begin{abstract}
$\mathrm{O}$ complexo $\left[\mathrm{Fe}_{2}{ }_{2}{ }^{\mathrm{II}}(\mathrm{BPClNOL})_{2}\left(\mathrm{SO}_{4}\right)\right] 3$ foi sintetizado pela reação do pré-ligante $\mathrm{N}-(2-$ hidroxibenzil)-N-(2-metilpiridil)[(3-cloro)(2-hidroxi)]propilamina ( $\left.\mathrm{H}_{2} \mathrm{BPClNOL}\right)$ com $\mathrm{FeSO}_{4} \cdot 7 \mathrm{H}_{2} \mathrm{O}$. O composto oxidado apresenta absorção máxima em $519 \mathrm{~nm}\left(\varepsilon=1,40 \times 10^{3} \mathrm{dm}^{3} \mathrm{~mol}^{-1} \mathrm{~cm}^{-1}\right)$ e a espécie de valência mista absorve em $439 \mathrm{~nm}\left(\varepsilon=9,8 \times 10^{2} \mathrm{dm}^{3} \mathrm{~mol}^{-1} \mathrm{~cm}^{-1}\right)$. O processo de redução da espécie oxidada ocorre em $-0,843 \mathrm{~V} v s$. $\mathrm{Fc} / \mathrm{Fc}^{+}$. A espectroscopia Mössbauer confirmou que o composto 3 possui átomos de $\mathrm{Fe}^{3+}$, spin alto. Medidas magnéticas mostram que a unidade binuclear apresenta acoplamento antiferromagnético, $\mathrm{J} / \mathrm{k}_{\mathrm{B}}=-15 \mathrm{~K}\left(\mathrm{~J}=-10,4 \mathrm{~cm}^{-1}\right)$. O complexo $\left[\mathrm{Fe}_{2}{ }^{\mathrm{III}}(\mathrm{BPClNOL})_{2}\left(\mathrm{SO}_{4}\right)\right]$ 3 é o terceiro integrante de uma família de compostos binucleares de ferro sintetizados com o ligante $\mathrm{H}_{2} \mathrm{BPClNOL}\left(\left[\mathrm{Fe}_{2}{ }^{\mathrm{III}}(\mathrm{BPClNOL})_{2}(\mathrm{OAc})\right]^{+} \mathbf{1},\left[\mathrm{Fe}_{2}{ }^{\mathrm{III}}(\mathrm{BPCINOL})_{2}\left(\mathrm{H}_{2} \mathrm{O}\right)_{2}\right]^{2+} \mathbf{2}\right)$. A comparação das propriedades físico-químicas dos complexos indica que o número de grupos pontes, assim como a natureza dos mesmos, apresentam significativas influências sobre o espectro eletrônico e as propriedades eletroquímicas dos referidos complexos.
\end{abstract}

Complex $\left[\mathrm{Fe}_{2}{ }_{2}\right.$ III $\left.(\mathrm{BPClNOL})_{2}\left(\mathrm{SO}_{4}\right)\right] 3$ was synthesized through the reaction of the proligand $\mathrm{N}$-(2-hydroxybenzyl)-N-(2-pyridylmethyl)[(3-chloro)(2-hydroxy)]propylamine $\left(\mathrm{H}_{2} \mathrm{BPCINOL}\right)$ and $\mathrm{FeSO}_{4} \cdot 7 \mathrm{H}_{2} \mathrm{O}$. The maximum absorption for the oxidized compound was at $519 \mathrm{~nm}\left(\varepsilon=1.40 \times 10^{3} \mathrm{dm}^{3} \mathrm{~mol}^{-1} \mathrm{~cm}^{-1}\right)$ while that of the mixed-valence compound was at 439 $\mathrm{nm}\left(\varepsilon=9.8 \times 10^{2} \mathrm{dm}^{3} \mathrm{~mol}^{-1} \mathrm{~cm}^{-1}\right)$. The redox process to transform the oxidized compound to the mixed-valence form occurs at $\mathrm{E}_{1 / 2}=-0.843 \mathrm{~V} v s$. Fc/Fc'. The Mössbauer spectrum confirms the presence of $\mathrm{Fe}^{\mathrm{III}}$ high spin ions and the magnetic studies reveal a weak antiferromagnetically coupled dimer, $\mathrm{J} / \mathrm{k}_{\mathrm{B}}=-15 \mathrm{~K}\left(\mathrm{~J}=-10.4 \mathrm{~cm}^{-1}\right)$. Complex 3 is the third of a family of dinuclear iron compounds synthesized with the $\mathrm{H}_{2} \mathrm{BPClNOL}$ ligand ( $\left[\mathrm{Fe}_{2}{ }^{\mathrm{III}}(\mathrm{BPClNOL})_{2}(\mathrm{OAc})\right]^{+} \mathbf{1}$, $\left.\left[\mathrm{Fe}_{2}{ }^{\mathrm{III}}(\mathrm{BPClNOL})_{2}\left(\mathrm{H}_{2} \mathrm{O}\right)_{2}\right]^{2+} \mathbf{2}\right)$. Analysis of the physicochemical properties of these complexes allowed us to infer that the number and kind of bridging groups have a significant influence on their electrochemical and UV-Vis properties.

Keywords: diiron complexes, structural models, PAPs, X-ray structure

\section{Introduction}

The development of synthetic compounds to mimic the chemical properties and the reactivity of the active

*e-mail: adolfo@uenf.br site of metalloproteins has been considered a useful approach to understanding the structure and the action mode of these essential macromolecules. ${ }^{1}$ In this regard, the first step is the synthesis of ligands containing donor groups similar to those found in the metalloenzymes of interest. When the active site of the metalloenzyme is not 
well-known, the synthesis of a series of ligands with small structural differences and their respective complexes has allowed the control of the properties of these synthetic compounds and a hypothesis of the chemical structure of the active site of the metalloenzymes. A good example of this strategy is the development of synthetic compounds aimed at understanding the features of the active site of the Purple Acid Phosphatases (PAP). These compounds have been prepared mainly on the 1,3-diamino-2hydroxypropane $\mathrm{e}^{2,3}$ or 2,6-bis(aminomethyl)-4-methylphenol skeleton..$^{4-7}$

Purple acid phosphatases (PAPs) are iron-containing non-heme proteins involved in the regulation of phosphate and phosphorylated metabolite levels in a wide range of organisms. They have been isolated from a variety of mammalian (TRAP, ufPAP, bsPAP), plant (kbPAP, spPAP) and bacterial sources (afPAP, ncPAP). ${ }^{8}$

The enzymes from bovine spleen (bsPAP) and porcine uterus (ufPAP) have a dinuclear iron center in their active site, with two accessible oxidation states. The inactive form, $\mathrm{Fe}^{\mathrm{III}} \mathrm{Fe}^{\mathrm{III}}$, is characterized by typical visible absorption maxima between 550 and $570 \mathrm{~nm}(\varepsilon$ $\left.=4000 \mathrm{dm}^{3} \mathrm{~mol}^{-1} \mathrm{~cm}^{-1}\right)$, whereas the catalytically active $\mathrm{Fe}^{\mathrm{III}} \mathrm{Fe}^{\mathrm{II}}$ form is blue shifted, with absorption maxima between 505 and $510 \mathrm{~nm}\left(\varepsilon=4000 \mathrm{dm}^{3} \mathrm{~mol}^{-1} \mathrm{~cm}^{-1}\right)$. Electrochemical studies have revealed that the redox potential for the ufPAP is $0.367 \mathrm{~V}$ at $\mathrm{pH} 5.0$ and 0.306 $\mathrm{V}$ at pH 6.0 vs. NHE. ${ }^{9}$ Mössbauer spectra of ufPAP ${ }^{10}$ and bsPAP ${ }^{11}$ have shown that the iron centers are in distinct coordination environments. This has been confirmed by X-ray crystallographic studies on TRAP, ${ }^{12}$ rat bone, ${ }^{13}$ and ufPAP. ${ }^{14}$ Magnetic susceptibility studies have indicated an antiferromagnetic coupling constant $\mathrm{J}=-13 \mathrm{~cm}^{-1}$ at $\mathrm{pH}=5.6$ for the reduced form and $\mathrm{J}=$ $-9 \mathrm{~cm}^{-1}$ at $\mathrm{pH} 5.1$ for the oxidized form of bsPAP. ${ }^{15}$ These results indicate a $\mu$-hydroxo bridge between the iron centers.

The synthetic approach to mimicking the properties of PAPs usually begins with the design of dinucleating ligands containing phenolic groups in their structures. ${ }^{2-7,16-19}$ This is due to the high $\varepsilon$ values observed in electronic spectra of PAPs, which are attributed to a tyrosine $\rightarrow \mathrm{Fe}^{\mathrm{III}}$ charge transfer transition. Thus, such dinucleating ligands hold the two metal centers in close proximity and provide phenolate coordinating groups, allowing the study of the influence of such groups on the properties exhibited by the metal centers in the complexes as well as in the enzyme.

Before the elucidation of the X-ray molecular structure of PAPs, there was much debate regarding the number of tyrosine residues coordinated to the iron ions. Due to the high $\varepsilon$ value $\left(4000 \mathrm{dm}^{3} \mathrm{~mol}^{-1} \mathrm{~cm}^{-1}\right)$ the presence of two tyrosine residues bound to the non-reducible iron center at the PAPs active site was proposed, since studies with model compounds had shown that each phenolate group represents a contribution of between 1000 and $2000 \mathrm{dm}^{3}$ $\mathrm{mol}^{-1} \mathrm{~cm}^{-1}$ to the $\varepsilon$ value. ${ }^{20}$ However, synthetic compounds possessing two phenolate groups have electrochemical properties significantly different from those observed for PAPs. Thus, based on the redox potential of synthetic compounds containing variable numbers of phenolate groups, it was proposed that in the PAPs active site there must be only one tyrosine group present. ${ }^{18}$

The elucidation of the molecular structure through $\mathrm{X}$-ray diffraction of a number of different PAP enzymes has shown unequivocally that only one tyrosine residue is present in their active site, this being bound to the nonreducible iron ion. ${ }^{12-14}$

As part of our continuing investigation into dinuclear iron complexes as models for the active site of PAPs, , $, 5-7,17-19^{-19}$ we have developed the dinucleating ligand $\mathrm{N}-(2-$ hydroxybenzyl)-N-(2-pyridylmethyl)[(3-chloro)(2hydroxy)]propylamine ( $\left.\mathrm{H}_{2} \mathrm{BPClNOL}\right)$. The synthesis, characterization and nuclease activity of two dinuclear iron compounds containing the ligand $\mathrm{H}_{2} \mathrm{BPClNOL}, \quad\left[\mathrm{Fe}_{2}{ }^{\mathrm{III}}(\mathrm{BPClNOL})_{2}(\mathrm{OAc})\right] \mathrm{ClO}_{4} \mathbf{1}$ and $\left[\mathrm{Fe}_{2}{ }_{2} \mathrm{II}(\mathrm{BPClNOL})_{2}\left(\mathrm{H}_{2} \mathrm{O}\right)_{2}\right]\left(\mathrm{ClO}_{4}\right)_{2} \cdot 4\left(\mathrm{H}_{2} \mathrm{O}\right) 2$, have been previously described. ${ }^{21,22}$ Although the same ligand was used in the synthesis of complexes $\mathbf{1}$ and $\mathbf{2}$ (Table 1), the compounds exhibited distinct structural and physicochemical properties. In 1 the ligand $\mathrm{H}_{2} \mathrm{BPCINOL}$ showed a facial coordination mode and three bridging groups were formed (two alkoxo and one acetate), while in $\mathbf{2}$ the ligand showed a meridional coordination mode with only two alkoxo bridges. Distinct electrochemical, electronic and magnetic behaviors were also observed. The differences in the physicochemical properties of compounds $\mathbf{1}$ and $\mathbf{2}$ were attributed to the presence of a different number of bridging groups. In order to understand other factors that can influence the properties of the diiron unit, we describe herein the synthesis and characterization of a new diiron compound containing the ligand $\mathrm{H}_{2} \mathrm{BPClNOL}$. This new member of the family $\mathrm{H}_{2} \mathrm{BPCINOL}$, $\left[\mathrm{Fe}_{2}{ }_{2} \mathrm{II}(\mathrm{BPClNOL})_{2}\left(\mathrm{SO}_{4}\right)\right]$ 3, was designed to study the influence of the sulfate anion on the diiron center, since only a low number of diiron compounds containing the $\mu$-sulfate bridge are reported in the literature ${ }^{7,23}$ and, to the best of our knowledge, not a single compound containing the alkoxo and sulfate bridge has been described to date. This study is of relevance since it can be used to understand why PAPs are inactivated by some tetroxide anions and also to show a different way to control the physicochemical properties of synthetic compounds. 
Table 1. Scheme of synthesis and some physicochemical properties for complexes 1, 2, and $\mathbf{3}$

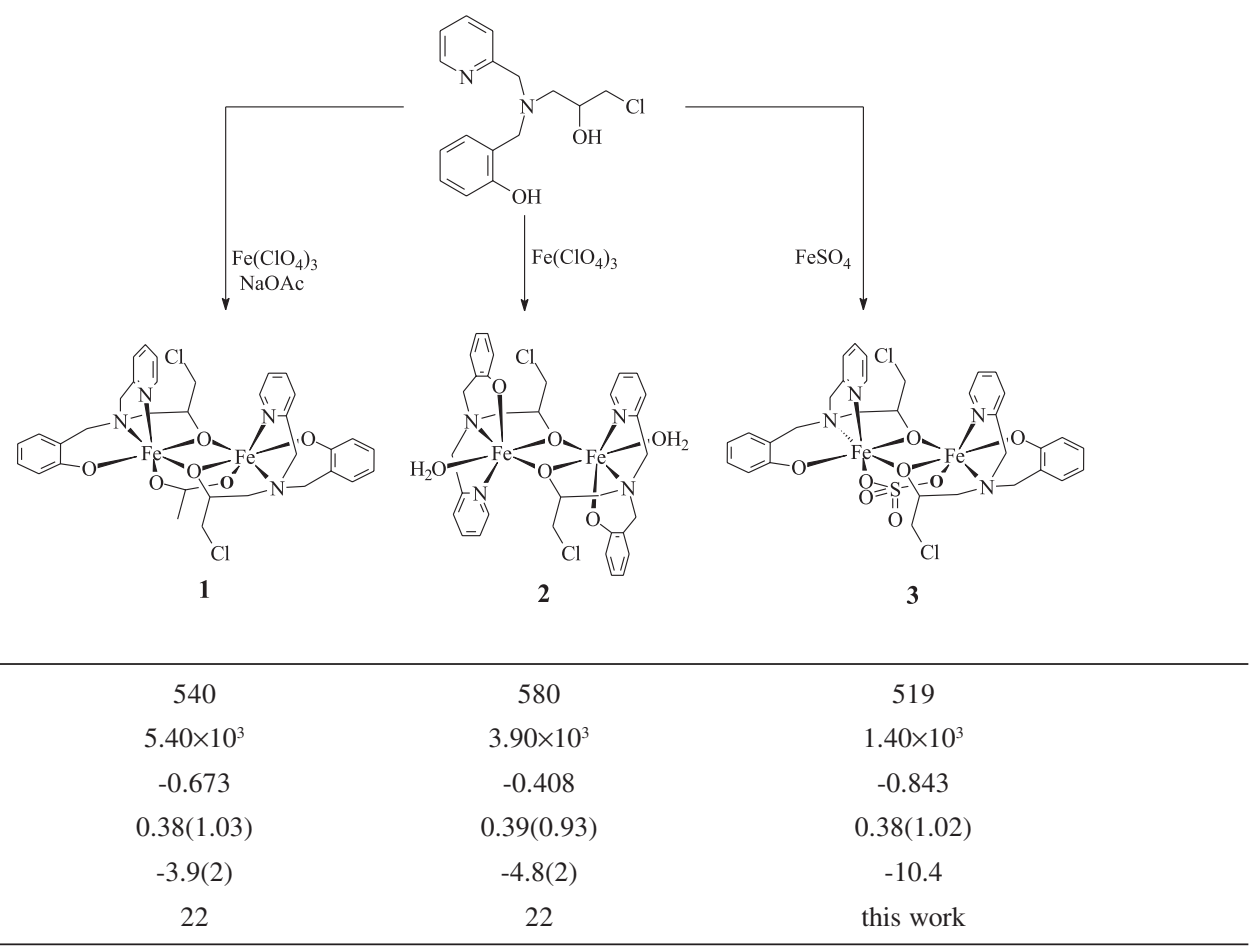

\section{Experimental}

\section{Materials and general methods}

All reagents and solvents were purchased from commercial sources and used as received. The elemental analysis was carried out with a Carlo Erba CHNS-O-E1110 Instrument. For the electrochemical experiments, spectroscopic grade solvents were used. The electrical conductivity of $c a .1 \times 10^{-3} \mathrm{~mol} \mathrm{dm}^{-3}$ solutions of 3 in acetonitrile was measured with a Digimed conductivity bridge-type CD-21 meter. The IR spectra was collected from $\mathrm{KBr}$ pellets using a Perkin-Elmer 1600 spectrometer. A Perkin-Elmer Lambda-19 spectrophotometer was used to record UV-Vis absorption spectra and to carry out spectroelectrochemical experiments. Electrochemical experiments were performed on a Princeton Applied Research 273 or $263 \mathrm{~A}$ potentiostat/galvanostat. The supporting electrolyte was $0.1 \mathrm{~mol} \mathrm{dm}^{-3} \mathrm{TBAPF}_{6}$ in acetonitrile. Cyclic voltammograms were obtained with a platinum disk working electrode, platinum wire as an auxiliar electrode, and a saturated calomel reference electrode. Ferrocene was used as an internal standard, $0.400 \mathrm{~V} v s$. NHE being considered. ${ }^{24}$ Spectroelectrochemistry was performed using an optically transparent thin-layer cell as previously described. ${ }^{25}$ The ferrocenium/ferrocene couple was used to monitor the reference electrode. ${ }^{24}$ Mössbauer spectra were measured at $298 \mathrm{~K}$ and $115 \mathrm{~K}$ against a ${ }^{57} \mathrm{Co}(\mathrm{Rh})$ source, operating in the constant acceleration mode. Velocity calibration was carried out through the resonance lines of metallic iron, and isomer shifts were given relative to metallic iron at room temperature. Magnetization measurements were done in a Quantum Design PPMS magnetometer/susceptometer, in the temperature range 2 to $300 \mathrm{~K}$ and with field up to $90 \mathrm{kOe}$.

\section{Syntheses}

$\mathrm{H}_{2} \mathrm{BPClNOL}$ ligand: the ligand was synthesized as described previously. ${ }^{21,22}$

Complex $\left[\mathrm{Fe}_{2}(\mathrm{BPClNOL})_{2}\left(\mathrm{SO}_{4}\right)\right] \cdot \mathrm{H}_{2} \mathrm{O} \cdot \mathrm{CH}_{3} \mathrm{OH}$ 3. Solid Iron(II) sulfate ( $2 \mathrm{mmol}, 0.56 \mathrm{~g}$ ) was added to a methanolic solution of $\mathrm{H}_{2} \mathrm{BPClNOL}(2 \mathrm{mmol}, 0.61 \mathrm{~g}$, $20 \mathrm{~cm}^{3}$ ). The initial orange solution slowly becomes purple. After one week, deep blue crystals were obtained, which were filtered off and washed with cold 2-propanol and ether. The solid was dried in vacuo. The yield was $1.00 \mathrm{~g}, 60 \%$. Anal. Found. C, 45.31; H, 3.97; N, 6.30; S, 3,60. Calc. for $\mathrm{Fe}_{2} \mathrm{C}_{33} \mathrm{H}_{40} \mathrm{~N}_{4} \mathrm{Cl}_{2} \mathrm{O}_{10} \mathrm{~S}$ : $\mathrm{C}, 45.69 ; \mathrm{H}, 4.34 ; \mathrm{N}, 6.46, \mathrm{~S}, 3.69 \% . \Lambda_{\mathrm{M}}=16 \Omega^{-1}$ $\mathrm{mol}^{-1} \mathrm{~cm}^{2}$. IR $v_{\max } / \mathrm{cm}^{-1}: 3450,1600,1568,1480,1450$, 1274, 1212, 1126, 1076, 980, 750. 


\section{$X$-ray crystallography}

Crystals of $\mathbf{3}$ are sensitive to solvent lost, so the crystals were handled in protective oil. A prismatic crystal was selected from the crystalline sample and isolated in a glass capillary for X-ray analysis. The intensity data were collected with an Enraf-Nonius CAD4 diffractometer, at room temperature, with graphite-monochromated Mo-K $\alpha$ radiation. Cell parameters were determined from 25 carefully centered reflections using a standard procedure. ${ }^{26}$ All data were corrected for Lorentz and polarization effects. ${ }^{27} \mathrm{An}$ empirical absorption correction based on the $\Psi$-scans was also applied to the collected intensities with the PLATON program $\left(\mathrm{T}_{\min }=0.731 ; \mathrm{T}_{\max }=0.821\right) .{ }^{28}$ The structure was solved by direct methods and refined by full-matrix least-squares methods using SIR97 ${ }^{29}$ and SHELXL $97^{30}$ programs, respectively. All non-hydrogen atoms were refined anisotropically.

$\mathrm{H}$ atoms bonded to carbon atoms were added in their calculated positions and included in the structure factor calculations with $\mathrm{C}$-H distances of 0.93-0.96 $\AA$ and $\mathrm{U}_{\text {iso }}(\mathrm{H})=1.2 \mathrm{U}_{\text {eq }}(\mathrm{C})$, or $1.5 \mathrm{U}_{\text {eq }}(\mathrm{C})$ for methyl groups. The water molecule is disordered over two alternative positions with occupancy factors of 0.54(4) and 0.46(4) and its $\mathrm{H}$ atoms and the $\mathrm{H}$ atom of the methanol solvent were not found on the Fourier map. Although complex $\mathbf{3}$ crystallizes in a non-centrosymmetric space group, the absolute structure was not established. Further relevant crystallographic data are summarized in Table 2.

\section{Results and Discussion}

The $\mathrm{H}_{2} \mathrm{BPCINOL}$ ligand was synthesized employing the method previously described in the literature. ${ }^{21,22}$ The reaction between the secondary amine $\mathrm{HBPA}^{5}$ and epichlorohydrin follows a mechanism for base-catalyzed ring opening, resulting in a secondary alcohol. ${ }^{31}$ Thus, epichlorohydrin has been shown to be an adequate reagent to introduce an alcohol function into the structure of ligands. ${ }^{32}$

We have previously described the chemical reactivity of the ligand $\mathrm{H}_{2} \mathrm{BPCINOL}$ with iron(III) perchlorate, ${ }^{21,} 22$ which results in dinuclear iron complexes with di- $\mu$-alkoxo- $\mu$-acetate and di- $\mu$-alkoxo units $\left[\mathrm{Fe}_{2}{ }_{2} \mathrm{II}(\mathrm{BPClNOL})_{2}(\mathrm{OAc})\right]\left(\mathrm{ClO}_{4}\right) \quad \mathbf{1}$ and $\left[\mathrm{Fe}_{2}{ }^{\mathrm{III}}(\mathrm{BPClNOL})_{2}\left(\mathrm{H}_{2} \mathrm{O}\right)_{2}\right]\left(\mathrm{ClO}_{4}\right)_{2} 2$, respectively) using distinct amounts of NaOAc in the reactions. In both complexes the alkoxo groups of $\mathrm{H}_{2} \mathrm{BPClNOL}$ bridge the $\mathrm{Fe}^{\mathrm{III}}$ centers. In the reaction of $\mathrm{H}_{2} \mathrm{BPClNOL}$ with $\mathrm{FeSO}_{4} \cdot 7 \mathrm{H}_{2} \mathrm{O}$, the ligand shows a similar behavior and the $\left[\mathrm{Fe}_{2}(\mathrm{BPClNOL})_{2}\left(\mathrm{SO}_{4}\right)\right] \mathbf{3}$ is formed. The infrared and elemental analyses indicated the presence of one sulfate bridge, which was confirmed by the X-ray molecular structure of $\mathbf{3}$. The presence of four infrared bands between $980-1212 \mathrm{~cm}^{-1}$ indicated the presence of the sulfate group with local symmetry lower than Td. After resolution of the crystal structure it was possible to confirm that its local symmetry is $\mathrm{C}_{2} \mathrm{v}$, in agreement with the infrared data. Conductometric analysis also indicated the presence of the sulfate group

Table 2. Selected crystal data and structure refinement for complex $\mathbf{3}$

\begin{tabular}{|c|c|}
\hline Empirical formula & $\mathrm{C}_{33} \mathrm{H}_{40} \mathrm{Cl}_{2} \mathrm{Fe}_{2} \mathrm{~N}_{4} \mathrm{O}_{10} \mathrm{~S}$ \\
\hline Formula weight & 867.35 \\
\hline Temperature & 293(2) K \\
\hline Wavelength & $0.71073 \AA$ \\
\hline Crystal system, space group & Orthorhombic, $\mathrm{P} 22_{1} 2_{1}$ \\
\hline \multirow[t]{3}{*}{ Unit cell dimensions } & $\mathrm{a}=13.115(3) \AA$ \\
\hline & $\mathrm{b}=14.647(3) \AA$ \\
\hline & $\mathrm{c}=18.936(4) \AA$ \\
\hline Volume & $3637.5(14) \AA^{3}$ \\
\hline Z, Calculated density & $4,1.584 \mathrm{Mg} / \mathrm{m}^{3}$ \\
\hline Absorption coefficient & $1.064 \mathrm{~mm}^{-1}$ \\
\hline $\mathrm{F}(000)$ & 1792 \\
\hline Crystal size & $0.47 \times 0.30 \times 0.23 \mathrm{~mm}$ \\
\hline Theta range for data collection & 2.35 to $28.00^{\circ}$ \\
\hline Index ranges & $0 \leq \mathrm{h} \leq 17,0 \leq \mathrm{k} \leq 19,0 \leq 1 \leq 25$ \\
\hline Reflections collected / unique & $4865 / 4865[\mathrm{R}(\mathrm{int})=0.0000]$ \\
\hline Refinement method & Full-matrix least-squares on $\mathrm{F}^{2}$ \\
\hline Data / restraints / parameters & $4865 / 0 / 481$ \\
\hline Goodness-of-fit on $\mathrm{F}^{2}$ & 1.024 \\
\hline Final $R$ indices $[I>2 \sigma(\mathrm{I})]$ & $\mathrm{R}_{1}=0.0409, \mathrm{wR}_{2}=0.0986$ \\
\hline $\mathrm{R}$ indices (all data) & $\mathrm{R}_{1}=0.0887, \mathrm{wR}_{2}=0.1077$ \\
\hline Largest diff. peak and hole & 0.507 and -0.585 e. $\AA^{-3}$ \\
\hline
\end{tabular}


coordinated to the iron atoms, since the value of 16 $\Omega^{-1} \cdot \mathrm{mol}^{-1} \mathrm{~cm}^{2}$ is related to a neutral compound. ${ }^{33}$

\section{Crystal structure of complex $\left[\mathrm{Fe}_{2}{ }_{2}{ }^{\mathrm{II}}(\mathrm{BPClNOL})_{2}\left(\mathrm{SO}_{4}\right)\right]$. $\mathrm{H}_{2} \mathrm{O} . \mathrm{MeOH}, 3$}

The atom arrangements and numbering scheme of $\mathbf{3}$ are shown in Figure 1. Selected bond lengths and angles are listed in Table 3. The X-ray crystallographic analysis confirms that $\mathbf{3}$ is a neutral molecule, which shows two hexacoordinated iron atoms. The metal centers are joined by one sulfate and two alkoxo bridges. Taking the equatorial planes as those including the alkoxo bridges $(\mathrm{O} 1, \mathrm{O} 2)$, the coordination around the $\mathrm{Fe}^{\mathrm{III}}$ centers is completed by the phenolic oxygen atoms $(\mathrm{O} 40, \mathrm{O} 20)$ and by the amine nitrogen atoms (N5, N1). Thus, the axial positions are occupied by the pyridine nitrogen atoms (N32, N12) located trans to the sulfate oxygen atoms. The alkoxo oxygen atoms are bonded asymmetrically to the iron atoms $(\mathrm{Fe} 1-\mathrm{O} 1=2.077(3) \AA, \mathrm{Fe} 2-\mathrm{O} 1=1.957(3)$ $\AA, \mathrm{Fe} 1-\mathrm{O} 2=1.940(3) \AA, \mathrm{Fe} 2-\mathrm{O} 2=2.084(3) \AA$ ). Comparing the structural features in compounds $\mathbf{1}, \mathbf{2}$ and $\mathbf{3}$, it is possible to infer that the third bridge (acetate in $\mathbf{1}$ and sulfate in $\mathbf{3}$ ) controls the ligand coordination mode around the iron atoms. In both complexes $\mathbf{1}$ and $\mathbf{3}$ the pendant arm of the ligand $\mathrm{H}_{2} \mathrm{BPClNOL}$ shows a facial coordination mode, while in $\mathbf{2}$, the same donor groups are coordinated in a meridional fashion. Furthermore, complex $\mathbf{3}$ helped us to confirm that the third bridging group $\left(\mu-\mathrm{SO}_{4}\right)$ prevents the $\mathrm{Fe}$ - $(\mu \text {-alkoxo })_{2}-\mathrm{Fe}$ unit from adopting a planar shape. Thus, only complex 2 , which contains only two alkoxo bridging groups, presents a planar Fe-( $\mu$-alkoxo $)_{2}$-Fe core, as confirmed by the sum of its inner angles $\left(360^{\circ}\right)$. As in $\mathbf{1}$, the presence of the third bridge in $\mathbf{3}$ promoted the approximation of the iron atoms $(\mathrm{Fe} \cdots \mathrm{Fe}$ for $\mathbf{1}=3.041(1) ; \mathbf{2}=3.122(1)$, and $\mathbf{3}=$ 3.0563(11) ^).

The $\mathrm{Fe}-\mathrm{O}_{\text {sulfate }}$ bond lengths in 3 ( $\mathrm{Fe} 1-\mathrm{O} 3=2.012(3)$, $\mathrm{Fe} 2-\mathrm{O} 4=2.002(4) \AA$ ) are slightly shorter than the Fe-O ${ }_{\text {acetate }}$ present in 1 [2.017(3), 2.034(3) $\AA$. In the dinuclear iron complex $\left(\mathrm{NH}_{4}\right)\left[\mathrm{Fe}_{2}{ }_{2}^{\mathrm{II}}(\mathrm{bbpmp})\left(\mathrm{SO}_{4}\right)_{2}\right]$ the Fe-OSO3 bond lengths are between 1.98(2) and 2.07(2) $\AA$. ${ }^{7}$

The packing arrangement of $\mathbf{3}$ is governed by both Van der Waals forces and hydrogen bonds. Once the $\mathrm{H}$ atoms of the methanol and of the disordered water were not found, the geometric parameters for the possible hydrogen bonds could not be determined. By geometric analysis (distances and angles), it can be considered that some H-bonds between water and sulfate group (O1W - O6 average 3.13 $\AA$ A, S1-O6-O1W $119.95^{\circ}$ ) and between methanol and sulfate group (O1S-O4 $2.99 \AA$, S1-O4-O1S $110.80^{\circ}$ ) are plausible.

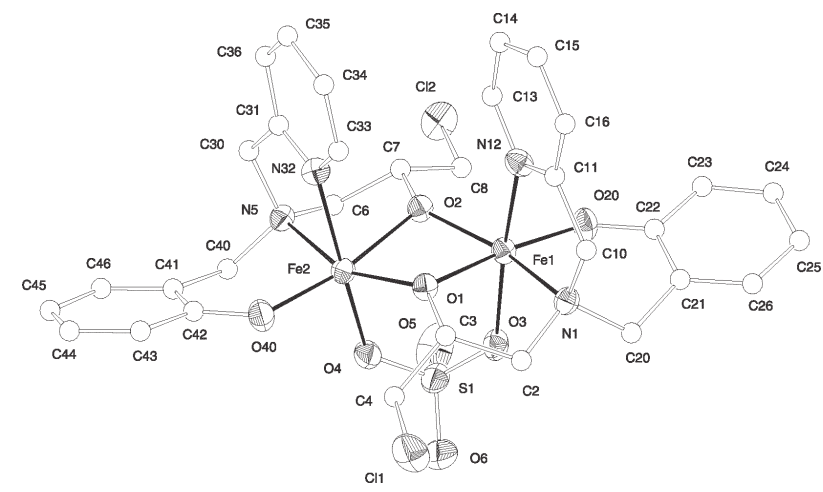

Figure 1. Molecular structure of the complex $\left[\mathrm{Fe}_{2}{ }^{\mathrm{III}}(\mathrm{BPClNOL})_{2}\left(\mathrm{SO}_{4}\right)\right]$, 3. Ellipsoids are shown at $40 \%$ probability level. Carbon atoms are shown with arbitrary size and $\mathrm{H}$ atoms were omitted for clarity.

\section{Electronic spectroscopy and electrochemical analysis}

The electronic spectrum of $\mathbf{3}$ measured in DMF solution exhibits two intense bands at $519 \mathrm{~nm}\left(\varepsilon=1.4 \times 10^{3}\right.$ $\left.\mathrm{dm}^{3} \mathrm{~mol}^{-1} \mathrm{~cm}^{-1}\right)$ and $327 \mathrm{~nm}\left(\varepsilon=3.2 \times 10^{3} \mathrm{dm}^{3} \mathrm{~mol}^{-1} \mathrm{~cm}^{-1}\right)$ and confirms the presence of $\mathrm{Fe}^{\mathrm{III}}$ ions. The band at lower energy is assigned as a phenolate $\mathrm{p} \pi \rightarrow \mathrm{d} \pi\left(\mathrm{Fe}^{\mathrm{III}}\right)$ ligand to metal charge transfer transition (LMCT), while the band at higher energy is attributed to a phenolate $\rightarrow \mathrm{Fe}^{\mathrm{III}}$ charge transfer involving $\mathrm{p} \pi \rightarrow \mathrm{d} \sigma^{*}$ orbitals. ${ }^{34}$

It is important here to compare the electronic spectral data of $\mathbf{3}$ with those of compounds $\mathbf{1}$ and $\mathbf{2}$, which show $\lambda_{\text {max }}$ at $540 \mathrm{~nm}\left(\varepsilon=5.4 \times 10^{3} \mathrm{dm}^{3} \mathrm{~mol}^{-1} \mathrm{~cm}^{-1}\right)$ and at $580 \mathrm{~nm}$ $\left(\varepsilon=3.9 \times 10^{3} \mathrm{dm}^{3} \mathrm{~mol}^{-1} \mathrm{~cm}^{-1}\right)$, respectively. The main difference between these complexes lies in the number and type of bridging groups, since the same ligand was used to form the compounds. While $\mathbf{3}$ has one sulfate and two alkoxo bridges, $\mathbf{1}$ has one acetate and two alkoxo bridges and $\mathbf{2}$ has only two alkoxo bridges (in $\mathbf{2}$ the positions occupied by the third bridge in $\mathbf{1}$ and $\mathbf{3}$ are occupied by water molecules). Thus, as discussed previously, ${ }^{22}$ the increase in the number of bridging groups resulted in significant displacement of the $\lambda_{\max }$ of the transition $\mathrm{p} \pi \rightarrow \mathrm{d} \pi\left(\mathrm{Fe}^{\mathrm{III}}\right)$ to higher energies $(\mathbf{3}>\mathbf{1}>\mathbf{2})$. From the data it becomes evident that the change in the third bridging group from acetate (monoanion) to sulfate (dianion), although not affecting significantly the structural parameters, has an important influence on the electronic properties of these complexes. In fact, this effect may be related to the decrease in the Lewis acidity of the iron centers, due to the increase in the number of better $\mathrm{O}$-donor $\left(\mathrm{OAc}^{-}\right.$and $\mathrm{SO}_{4}{ }^{2-}$ in $\mathbf{1}$ and $\mathbf{3}$, respectively, instead of $\mathrm{H}_{2} \mathrm{O}$ in 2) groups which makes the energy of the $t_{2 \mathrm{~g}}$ orbitals in $\mathbf{3}$ and $\mathbf{1}$ higher than that in $\mathbf{2}$ and therefore, higher energy radiation is necessary to promote the LMCT process. Similar behavior has been observed when the acetate bridges in the complex $\left[\mathrm{Fe}_{2}(\mathrm{BBPMP})(\mathrm{OAc})_{2}\right]^{2+}$ 
Table 3. Selected bond distances $(\AA)$ and angles $\left(^{\circ}\right)$ for complex $\left[\mathrm{Fe}_{2}^{\mathrm{III}}(\mathrm{BPClNOL})_{2}\left(\mathrm{SO}_{4}\right)\right], 3$

\begin{tabular}{|c|c|c|c|}
\hline $\mathrm{Fe} 1-\mathrm{O} 20$ & $1.878(3)$ & $\mathrm{Fe} 2-\mathrm{O} 40$ & $1.878(4)$ \\
\hline $\mathrm{Fe} 1-\mathrm{O} 2$ & $1.940(3)$ & Fe2-O1 & $1.957(3)$ \\
\hline $\mathrm{Fe} 1-\mathrm{O} 3$ & $2.012(3)$ & $\mathrm{Fe} 2-\mathrm{O} 4$ & $2.002(4)$ \\
\hline Fe1-O1 & $2.077(3)$ & $\mathrm{Fe} 2-\mathrm{O} 2$ & $2.084(3)$ \\
\hline Fe1-N12 & $2.149(4)$ & $\mathrm{Fe} 2-\mathrm{N} 32$ & $2.169(4)$ \\
\hline Fe1-N1 & $2.181(4)$ & Fe2-N5 & $2.182(4)$ \\
\hline $\mathrm{Fe} 1 \cdots \mathrm{Fe} 2$ & $3.0563(11)$ & & \\
\hline $\mathrm{O} 20-\mathrm{Fe} 1-\mathrm{O} 2$ & $110.16(14)$ & $\mathrm{O} 40-\mathrm{Fe} 2-\mathrm{O} 1$ & $111.86(14)$ \\
\hline $\mathrm{O} 20-\mathrm{Fe} 1-\mathrm{O} 3$ & $92.37(15)$ & $\mathrm{O} 40-\mathrm{Fe} 2-\mathrm{O} 4$ & $93.15(16)$ \\
\hline O2-Fe1-O3 & $95.17(14)$ & $\mathrm{O} 1-\mathrm{Fe} 2-\mathrm{O} 4$ & $92.82(14)$ \\
\hline O20-Fe1-O1 & $170.69(14)$ & $\mathrm{O} 40-\mathrm{Fe} 2-\mathrm{O} 2$ & $168.77(14)$ \\
\hline O2-Fe1-O1 & 79.04(13) & O1-Fe2-O2 & $78.47(12)$ \\
\hline O3-Fe1-O1 & $88.06(14)$ & $\mathrm{O} 4-\mathrm{Fe} 2-\mathrm{O} 2$ & $90.61(14)$ \\
\hline O20-Fe1-N12 & $90.72(17)$ & $\mathrm{O} 40-\mathrm{Fe} 2-\mathrm{N} 32$ & $91.01(17)$ \\
\hline $\mathrm{O} 2-\mathrm{Fe} 1-\mathrm{N} 12$ & $93.65(15)$ & O1-Fe2-N32 & $92.61(14)$ \\
\hline O3-Fe1-N12 & $169.02(15)$ & $\mathrm{O} 4-\mathrm{Fe} 2-\mathrm{N} 32$ & $171.41(15)$ \\
\hline O1-Fe1-N12 & $87.20(14)$ & $\mathrm{O} 2-\mathrm{Fe} 2-\mathrm{N} 32$ & $83.95(15)$ \\
\hline $\mathrm{O} 20-\mathrm{Fe} 1-\mathrm{N} 1$ & $92.09(15)$ & $\mathrm{O} 40-\mathrm{Fe} 2-\mathrm{N} 5$ & $91.05(15)$ \\
\hline O2-Fe1-N1 & $156.52(15)$ & O1-Fe2-N5 & $155.99(14)$ \\
\hline O3-Fe1-N1 & 91.14(14) & $\mathrm{O} 4-\mathrm{Fe} 2-\mathrm{N} 5$ & $92.98(14)$ \\
\hline O1-Fe1-N1 & $78.60(14)$ & $\mathrm{O} 2-\mathrm{Fe} 2-\mathrm{N} 5$ & $78.19(14)$ \\
\hline N12-Fe1-N1 & $78.21(15)$ & N32-Fe2-N5 & $79.42(14)$ \\
\hline $\mathrm{Fe} 1-\mathrm{O} 2-\mathrm{Fe} 2$ & $98.78(14)$ & O3-S1-O4 & 107.5(3) \\
\hline $\mathrm{Fe} 2-\mathrm{O} 1-\mathrm{Fe} 1$ & $98.44(13)$ & & \\
\hline
\end{tabular}

$\left(\lambda_{\max }=601 \mathrm{~nm}\right)^{5}$ are replaced by sulfate bridges, resulting in the complex $\left[\mathrm{Fe}_{2}{ }^{\mathrm{III}}(\mathrm{BBPMP})\left(\mathrm{SO}_{4}\right)_{2}\right]\left(\lambda_{\max }=587 \mathrm{~nm}\right){ }^{7}$ Moreover the same tendency has been observed with bsPAP. Addition of acetate resulted in displacement of $\lambda_{\text {max }}$ from $558 \mathrm{~nm}(\mathrm{pH} \mathrm{5.2)}$ to $550 \mathrm{~nm}$, while addition of sulfate changed $\lambda_{\text {max }}$ to $546 \mathrm{~nm}^{35}$

The cyclic voltammogram of $\mathbf{1}$ in DMF (Figure 2) in the range of 1.0 to $-2.0 \mathrm{~V}$ shows only one reversibly wave at $-0.843 \mathrm{~V}$ vs. $\mathrm{Fc} / \mathrm{Fc}^{+}$which is ascribed to the $\mathrm{Fe}_{2}^{\mathrm{III}} \rightarrow \mathrm{Fe}^{\mathrm{III}} \mathrm{Fe}^{\mathrm{II}}$ redox process. Thus, compound 3 shows a redox potential which is cathodically shifted when compared to $\mathbf{1}\left(\mathrm{E}_{1 / 2}=-0.673 \mathrm{~V}\right.$ vs. $\left.\mathrm{Fc} / \mathrm{Fc}^{+}\right)$and $2(-0.408$ $\mathrm{V}$ vs. $\left.\mathrm{Fc} / \mathrm{Fc}^{+}\right)$. A similar behavior has been reported for other dinuclear $\left[\mu\right.$-phenolate $\left.(\mu-\mathrm{OAc})_{2}\right]$ iron compounds. ${ }^{5,7}$

Spectroelectrochemical studies (Figure 3) were performed in order to characterize the UV-Vis properties of the mixed-valence $\mathrm{Fe}^{\mathrm{III}} \mathrm{Fe}^{\mathrm{II}}$ form of $\mathbf{3}$. The reduction $\left(\mathrm{Fe}_{2}^{\mathrm{III}} \rightarrow \mathrm{Fe}^{\mathrm{III}} \mathrm{Fe}^{\mathrm{II}}\right)$ of complex 3 resulted in a hypsochromic shift in the absorption maximum from 519 to $439 \mathrm{~nm}\left(\varepsilon=9.8 \times 10^{2} \mathrm{dm}^{3} \mathrm{~mol}^{-1} \mathrm{~cm}^{-1}\right)$. The maintenance of isosbestic points in successive spectra strongly corroborates the presence of a single product during the course of the electrolysis. The Nernst plot revealed $\mathrm{E}_{1 / 2}=-0.883 \mathrm{~V}$ vs. $\mathrm{Fc} / \mathrm{Fc}^{+}$, in full agreement with the data from the cyclic voltammetry. A total of $0.92 \pm 1$ electrons was available in the process. The

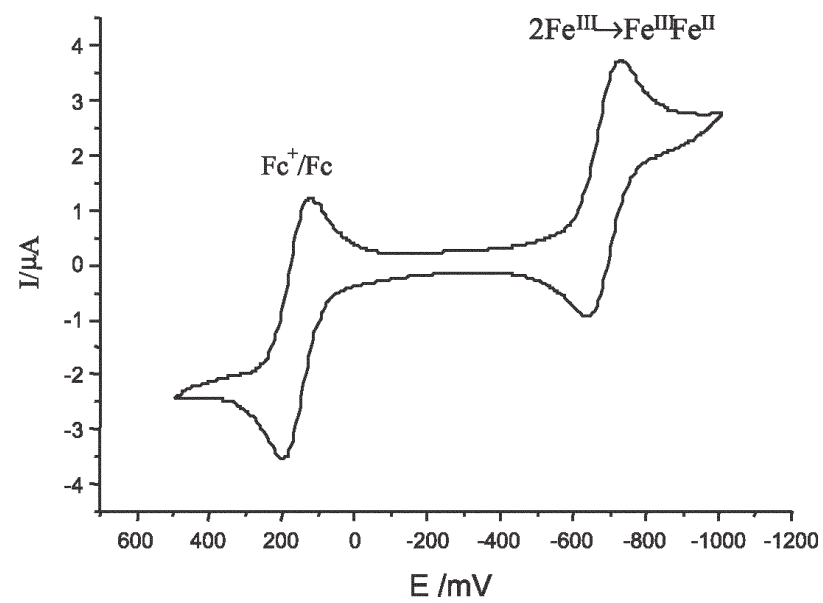

Figure 2. Cyclic voltammogram of the complex $\left[\mathrm{Fe}^{\mathrm{III}}{ }_{2}(\mathrm{BPClNOL})_{2}\left(\mathrm{SO}_{4}\right)\right]$, 3 in DMF with $0.1 \mathrm{~mol} \mathrm{dm}^{-3} \mathrm{TBAPF}_{6}$ at $100 \mathrm{mV} \mathrm{s}^{-1}$ scan rate. Ferrocene was used as the internal standard.

experiment also revealed a hypochromic effect, which can be explained by the presence of only one LMCT phenolate $\rightarrow \mathrm{Fe}^{\mathrm{III}}$ process in the reduced form of $\mathbf{3}$, while in the oxidized species there are two similar processes due to the presence of two Fe ${ }^{I I I}$ ions.

In summary, the electrochemical results for 1, $\mathbf{2}$ and $\mathbf{3}$ reveal that the $\mathrm{Fe}^{\mathrm{III}} / \mathrm{Fe}^{\mathrm{II}}$ redox potentials for this series of complexes are mainly controlled by the basicity of the exogeneous bridging ligand $\left(\mathrm{OAc}^{-}\right.$or $\left.\mathrm{SO}_{4}{ }^{2-}\right)$ as was also observed through the UV-Vis properties. Interestingly, plots of $\lambda_{\text {max }}$ of the LMCT band vs. the redox potential for 


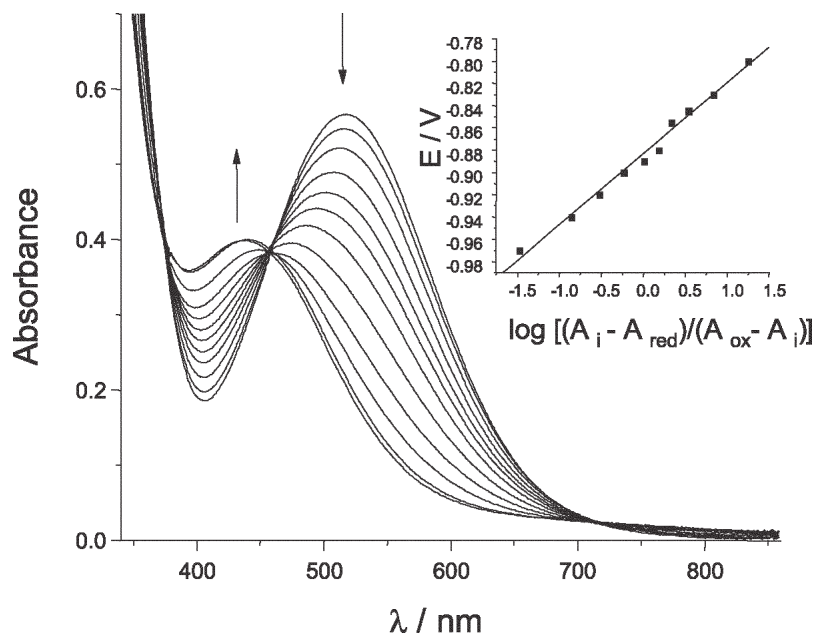

Figure 3. Spectra recorded during spectropotentiostatic experiment of complex $\left[\mathrm{Fe}_{2}^{\mathrm{III}}(\mathrm{BPClNOL})_{2}\left(\mathrm{SO}_{4}\right)\right], 3$. The inset shows the Nernst plot. Applied potentials in $\mathrm{V}$ vs. $\mathrm{Fc} / \mathrm{Fc}^{+}$are: $-0.800,-0.830,-0.845,-0.855$, $-0.880,-0.890,-0.900,-0.920,-0.940,-0.970$.

the oxidized as well as for the mixed-valence forms of complexes 1, $\mathbf{2}$ and $\mathbf{3}$ show linear correlations (Figure 4), indicating that both of the properties are affected in the same proportion by variations in the bridging groups.

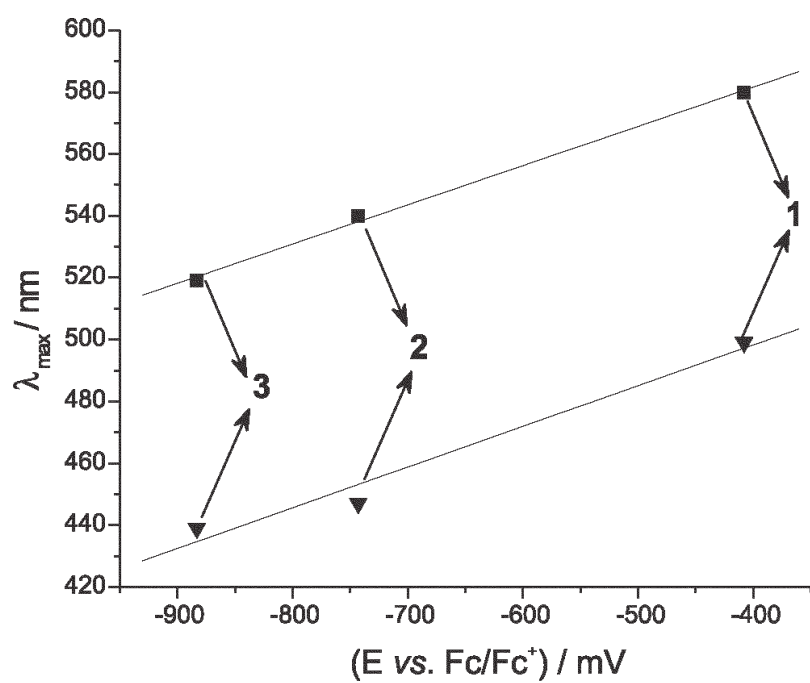

Figure 4. Plot of $\lambda_{\text {max }}\left(\boldsymbol{\square}=\mathrm{Fe}^{\mathrm{II}} \mathrm{Fe}^{\mathrm{III}}\right.$ and $\left.\boldsymbol{\nabla}=\mathrm{Fe}^{\mathrm{III}} \mathrm{Fe}^{\mathrm{II}}\right)$ vs. redox potential for complexes $\mathbf{1}, \mathbf{2}$ and $\mathbf{3}$.

\section{Mössbauer spectroscopy and magnetochemistry}

The Mössbauer spectrum (Figure 5) of $\mathbf{3}$ are typical of $\mathrm{Fe}^{\mathrm{III}}$ ions $\left(\delta=0.38, \Delta \mathrm{E}_{\mathrm{q}}=1.02 \mathrm{~mm} \mathrm{~s}^{-1}\right.$ at $295 \mathrm{~K}$ and $\delta=$ $0.47, \Delta \mathrm{E}_{\mathrm{q}}=1.08 \mathrm{~mm} \mathrm{~s}^{-1}$ at $\left.115 \mathrm{~K}\right) .{ }^{36}$ The spectra are almost symmetrical at both temperatures. However, when the temperature is reduced from $295 \mathrm{~K}$ to $115 \mathrm{~K}$ an inversion of the signal intensities is observed, which can be considered as being an anomalous behavior. The same feature was observed in $\mathbf{1}$ and $\mathbf{2}$, which suggests that a pronounced Zero Field Splitting at the iron nuclei produces this effect. ${ }^{22}$

Comparing all the physicochemical methods employed up to now in the study of complexes $\mathbf{1}, \mathbf{2}$ and $\mathbf{3}$, the Mössbauer spectroscopy was the least sensitive to the changes in the bridging groups. Although the exogeneous donor groups around the iron atoms are different in the complexes, the type of atoms directly bound to the metal ions is the same (in all the complexes the iron atoms have a $\mathrm{N}_{2} \mathrm{O}_{4}$ coordination environment). This fact explains the lack of significant changes in the isomer shift $(\delta)$ values. Considering the quadrupole splitting $\Delta \mathrm{E}_{\mathrm{q}}$, all the complexes have a pseudo octahedral geometry around the iron nuclei; however, the crystallographic data confirms that complex $\mathbf{2}$ is the least distorted, and thus it has the lowest $\Delta \mathrm{E}_{\mathrm{q}}$ value.
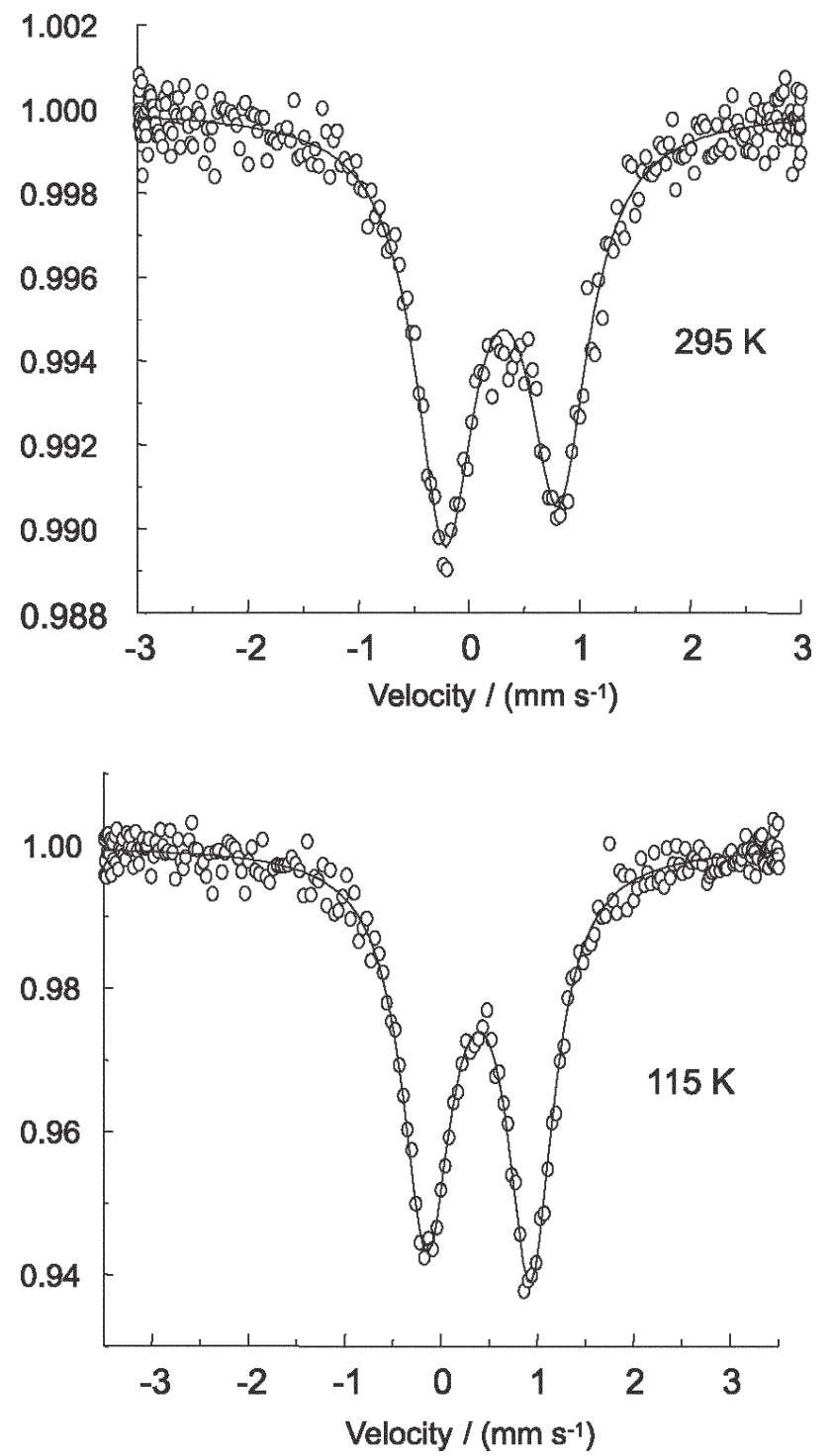

Figure 5. Mössbauer spectrum of complex $\left[\mathrm{Fe}_{2}^{\mathrm{III}}(\mathrm{BPClNOL})_{2}\left(\mathrm{SO}_{4}\right)\right] 3$ at 295 and $115 \mathrm{~K}$. 
Magnetization measurements, as a function of temperature, were carried out under a field of $1 \mathrm{kOe}$, from $2.5 \mathrm{~K}$ up to room temperature. In addition, we performed magnetization measurements as a function of field up to $90 \mathrm{kOe}$ at 2,4 and $8 \mathrm{~K}$. The susceptibility $\chi$ results obtained are plotted as $\chi$ versus $\mathrm{T}$ shown in Figure 6 . We fitted these data using an isotropic Heisenberg Hamiltonian suitable for describing high $\operatorname{spin}\left(\mathrm{S}_{\mathrm{A}}=\mathrm{S}_{\mathrm{B}}=5 / 2\right) \mathrm{Fe}^{\mathrm{III}}$ dimers in these surroundings, neglecting any zero-field splitting: $\mathrm{H}=-\mathrm{JS}_{\mathrm{A}} \cdot \mathrm{S}_{\mathrm{B}}+$ Zeeman interactions.

The susceptibility can thus be described by the expression:

$\chi=\left(\frac{2 N g^{2} \mu_{B}^{2}}{k_{B} T}\right)\left(\frac{e^{x}+5 e^{3 x}+14 e^{6 x}+30 e^{10 x}+55 e^{15 x}}{1+3 e^{x}+5 e^{3 x}+7 e^{6 x}+9 e^{10 x}+11 e^{15 x}}\right)$,

where $x=\frac{J}{k_{B} T}, \mathrm{~N}$ is the Avogadro number, $g$ is the Landee factor and $\mu_{\mathrm{B}}$ is the Bohr magneton. ${ }^{37}$ The best fit obtained is shown as a line in Figure 6, this being in agreement with an isotropic interacting dinuclear model using $g=2, \mathrm{~J} /$ $\mathrm{k}_{\mathrm{B}}=-15.0 \mathrm{~K}\left(\mathrm{~J}=-10.4 \mathrm{~cm}^{-1}\right)$ and not using any temperature independent contribution, in other words, the diamagnetism seems to be canceled by a TIP (Temperature Independent Paramagnetism) contribution. This result shows that complex $\mathbf{3}$ is weakly antiferromagnetically coupled, and the $\mathbf{J}$ value is in the range observed for similar complexes containing malkoxo bridge, including complexes $\mathbf{1}$ and $\mathbf{2}^{38}$

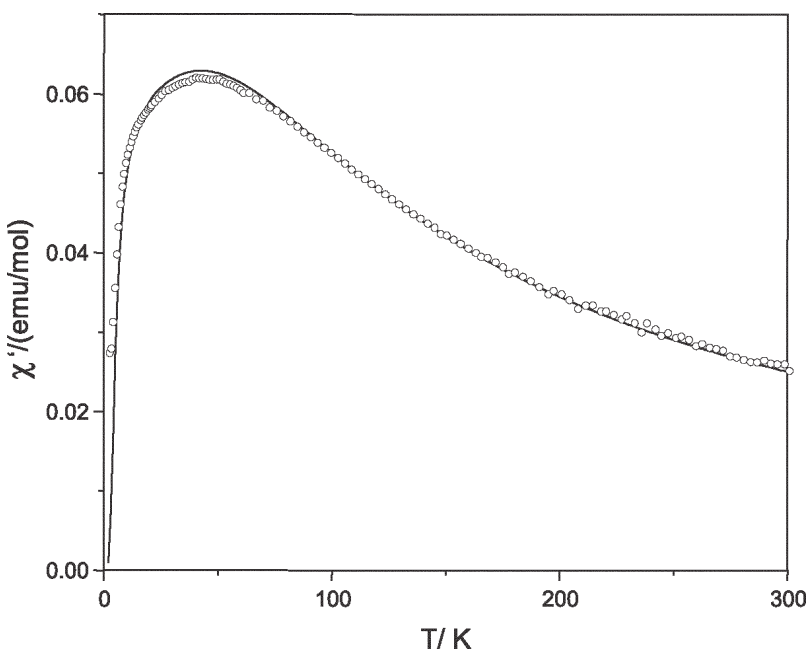

Figure 6. Magnetic susceptibility as a function of the temperature for complex $\left[\mathrm{Fe}_{2}^{\mathrm{III}}(\mathrm{BPClNOL})_{2}\left(\mathrm{SO}_{4}\right)\right], \mathbf{3}$.

The magnetization measurements given in Figure 7 are in agreement with the susceptibility and show an almost completely compensated antiferromagnetic dimer at the lowest temperature measured (2K). The spin-flop transition

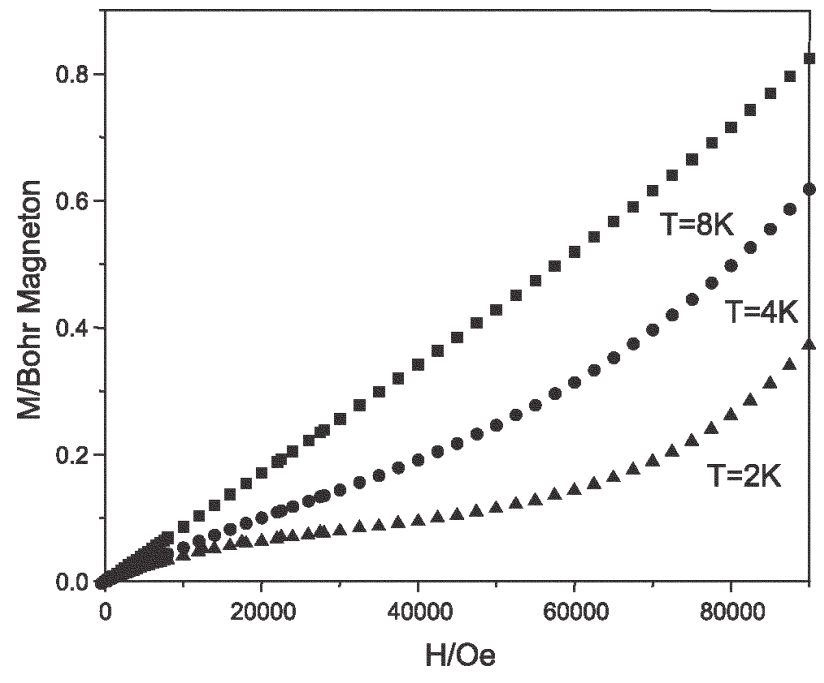

Figure 7. Magnetization as a function of the magnetic field for complex $\left[\mathrm{Fe}_{2}^{\mathrm{III}}(\mathrm{BPClNOL})_{2}\left(\mathrm{SO}_{4}\right)\right], 3$.

should occur at a much higher field than $90 \mathrm{kOe}$, as expected for an antiferromagnetic dimer with $\mathrm{J} / \mathrm{k}_{\mathrm{B}}=-15 \mathrm{~K}(\mathrm{~J}=-10.4$ $\left.\mathrm{cm}^{-1}\right)$. As the temperature is raised, it becomes easier to compete with the exchange interactions increasing the field and $\mathrm{M}$ becomes greater, but still well below the expected saturation moment of $10 \mathrm{Bohr}$ magnetons.

\section{Conclusions}

The study of the properties of the complex $\left[\mathrm{Fe}_{2}{ }_{2}{ }_{2}(\mathrm{BPClNOL})_{2}\left(\mathrm{SO}_{4}\right)\right] 3$, together with the data on the compounds $\left[\mathrm{Fe}_{2}{ }_{2}{ }_{2}(\mathrm{BPClNOL})_{2}(\mathrm{OAc})\right]^{+}, \mathbf{3}$ and $\left[\mathrm{Fe}^{\mathrm{III}}{ }_{2}\right.$ $\left.(\mathrm{BPClNOL})_{2}\left(\mathrm{H}_{2} \mathrm{O}\right)_{2}\right]^{2+}, \mathbf{2}$, allowed us to confirm that the number and kind of bridging groups have a great influence on some physicochemical properties of these diiron compounds. In fact, the electrochemical and UV-Vis properties are the most sensitive to the changes in the number and kind of the bridging groups. Nevertheless, the change in the exogenous bridge from acetate to sulfate does not seem to affect significantly the structural and Mössbauer parameters of these complexes.

Finally, this study demonstrates that the number and the kind of bridging groups must be considered in the search for mimetic compounds for metalloenzymes.

\section{Supplementary Information}

The crystallographic data (atomic coordinates and equivalent isotropic displacement parameters, calculated hydrogen atom parameters, anisotropic thermal parameters and bond lengths and angles) have been deposited at the Cambridge Crystallographic Data Center (deposition number CCDC 297918). Copies of this 
information may be obtained free of charge from: CCDC, 12 Union Road, Cambridge, CB2 1EZ, UK (Fax: +441223-336-033; e-mail: deposit@ccdc.cam.ac.uk or http://www.ccdc.cam.ac.uk).

\section{Acknowledgments}

The authors are grateful for grants from CNPq (Brazil), FINEP and FAPERJ.

\section{References}

1. Gavrilova, A. L.; Bosnich, B.; Chem. Rev. 2004, 104, 349; Mitic, N.; Smith, S. J.; Neves, A.; Guddat, L. W.; Gahan, L. R.; Schenk, G.; Chem. Rev. 2006, 106, 3338.

2. Neves, A.; Erthal, S. M. D.; Drago, V.; Griesar, K.; Haase, W.; Inorg. Chim. Acta 1992, 197, 121.

3. Krebs, B.; Schepers, K.; Bremer, B.; Henkel, G.; Althaus, E.; Müller-Warmuth W., Griesar, K.; Haase, W.; Inorg. Chem. 1994, 33, 1907.

4. Suzuki, M.; Uehara, A.; Oshio, H.; Endo, K.; Yanaga, M.; Kida, S.; Saito, K.; Bull. Chem. Soc. Jpn. 1987, 60, 3547; Suzuki, M.; Oshio, H.; Uehara, A.; Endo, K.; Yanaga, M.; Kida, S.; Saito, K.; Bull. Chem. Soc. Jpn. 1988, 61, 3907; Schepers, K; Bremer, B; Krebs, B.; Henkel, G.; Althaus, E.; Mosel, B.; Müller-Warmuth W.; Angew. Chem., Int. Ed. 1990, 29, 531; Bernard, E.; Moneta, W.; Laugier, J.; Chardon-Noblat, S.; Deronzier, A.; Tuchagues, J. P.; Latour, J. M.; Angew. Chem., Int. Ed. 1994, 33, 887; Ghiladi, M.; Mckenzie, C. J.; Meier, A.; Powell, A. K.; Ulstrup, J.; Wocadlo, S.; J. Chem. Soc., Dalton Trans. 1997, 4011; Lambert, E.; Chabut, B.; Chardon-Noblat, S.; Deronzier, A.; Chottard, G.; Bousseksou, A.; Tuchagues, J. P.; Laugier, J.; Bardet, M.; Latour, J. M.; J. Am. Chem. Soc. 1997, 119, 9424.

5. Neves, A.; Brito, M. A.; Vencato, I.; Drago, V.; Griesar, K.; Haase, W.; Mascarenhas, Y. P.; Inorg. Chim. Acta 1993, 214, 5.

6. Neves, A.; Brito, M. A.; Drago, V.; Griesar, K.; Haase, W.; Inorg. Chim. Acta 1995, 237, 131.

7. Brito, M. A.; Neves, A.; Vencato, I.; Zucco, C.; Drago, V.; Griesar, K.; Haase, W.; J. Braz. Chem. Soc. 1997, 8, 443.

8. Que, L. Jr.; True, A. E.; Prog. Inorg. Chem. 1990, 38, 97; Vincent, J. B.; Olivier-Lilley, G. L.; Averill, B. A.; Chem. Rev. 1990, 90, 1447; Lippard, S. J.; Angew. Chem., Int. Ed. 1988, 27, 344; Doi, K.; Antanaitis B. C.; Aisen, P.; Struct. Bond. 1988, 70, 1; Klabunde, T.; Krebs, B.; Struct. Bond. 1997, 89, 177.

9. Wang, L.; Holz, R. C.; David, S. S.; Que, L. Jr.; Stankovich, M. T.; Biochemistry 1991, 30, 8187.

10. Debrunner, P. G.; Hendrich, M. P.; Jersey, J.; Keough, D. T.; Sage, J. T.; Zerner, B.; Biochim. Biophys. Acta 1983, 745, 103; Rodriguez, J. H.; Ok, H. N.; Xia, Y.-M.; Debrunner, P. G.; Hinrichs, B. E.; Meyer, T.; Packard, N. H.; J. Phys. Chem. 1996, 100, 6849 .
11. Averill, B. A.; Davis, J. C.; Burman, S.; Zirino, T.; SandersLoehr, J.; Loehr, T. M.; Sage, J. T.; Debrunner, P. G.; J. Am. Chem. Soc. 1987, 109, 3760.

12. Uppenberg, J.; Lindqvist, F.; Svensson, C.; Ek-Rylander, B.; Andersson, G.; J. Mol. Biol. 1999, 290, 201.

13. Lindqvist, Y.; Johansson, E.; Kaija, H.; Vihko, P.; Schneider, G.; J. Mol. Biol. 1999, 291, 135.

14. Guddat, L. W.; McAlpine, A. S.; Hume, D.; Hamilton, S.; Jersey, J.; Martin, J. L.; Structure 1999, 7, 757.

15. Gehring, S.; Fleischhauer, P.; Behlendorf, M.; Hüber, M.; Lorösch, J.; Haase, W.; Dietrich, M.; Witzel, H.; Löcke, R.; Krebs, B.; Inorg. Chim. Acta 1996, 252, 13.

16. Borovik, A. S.; Papaefthymiou, V.; Taylor, L. F.; Anderson, O. P.; Que, L. Jr.; J. Am. Chem. Soc. 1989, 111, 6183; Bernard, E.; Chardon-Noblat, S.; Deronzier, A.; Latour, J. M.; Inorg. Chem. 1999, 38, 190; Belle, C.; Gautier-Luneau, I.; Pierre, J. L.; Scheer, C.; Inorg. Chem. 1996, 35, 3706; Yan, S.; Que; L. Jr.; Taylor, L. F.; Anderson, O. P.; J. Am. Chem. Soc. 1988, 110, 5222; Nie, H.; Aubin, S. M. J.; Mashuta, M. S.; Wu, C. C.; Richardson, J. F.; Hendrickson, D. N.; Buchanan, R. M.; Inorg. Chem. 1995, 34, 2382; Belle, C.; Pierre, J. L.; Eur. J. Inorg. Chem. 2003, 4137.

17. Neves, A.; Brito, M. A.; Vencato, I.; Drago, V.; Griesar, K.; Haase, W.; Inorg. Chem. 1996, 35, 2360.

18. Neves, A.; Rossi, L. M.; Vencato, I.; Haase, W.; Werner, R.; J. Chem. Soc., Dalton Trans. 2000, 707.

19. Lanznaster, M.; Neves, A.; Bortoluzzi, A. J.; Szpoganicz, B.; Schwingel, E.; Inorg. Chem. 2002, 41, 5641; Karsten, P.; Neves, A.; Bortoluzzi, A. J.; Drago, V.; Lanznaster, M.; Inorg. Chem. 2002, 41, 4624; Batista, S. C.; Neves, A.; Bortoluzzi, A. J.; Vencato, I.; Peralta, R. A.; Szpoganicz, B.; Aires, V. V. E., Terenzi, H.; Severino, P. C.; Inorg. Chem. Commun. 2003, 6, 1161.

20. Gaber, B. P.; Miskowski, V.; Spiro, T. G.; J. Am. Chem. Soc. 1974, 96, 6868; Ainscough, E. W.; Brodie, A. M.; Plowman, J. E.; Brown, K. L.; Addison, A. W.; Gainsford, A. R.; Inorg. Chem. 1980, 19, 3655.

21. Horn, A. Jr., Neves, A.; Vencato, I.; Zucco, C.; Drago, V.; Werner, R.; Haase, W.; J. Braz. Chem. Soc. 2000, 11, 7.

22. Horn , A. Jr., Vencato, I.; Bortoluzzi, A. J.; Hörner, R.; Nome Silva, R. A.; Szpoganicz, B.; Drago, V.; Terenzi, H.; Oliveira, M. C. B.; Werner, R.; Haase, W.; Neves, A.; Inorg. Chim. Acta 2005, 358, 339.

23. Holz, R. C.; Elgren, T. E.; Pearce, L. L.; Zhang, J. H.; O‘Connor, C. J.; Que, L. Jr. Inorg. Chem. 1993, 32, 5844; Scheidt, W. R.; Lee, Y. J.; Bartzcak, T.; Hatano, K.; Inorg. Chem. 1984, 23, 2552.

24. Gagné, R. R.; Koval, C. A.; Lisensky, G. C.; Inorg. Chem. 1980, 19, 2854.

25. Neves, A.; Erthal, S. M. D.; Vencato, I.; Ceccato, A. S.; Mascarenhas, Y. P.; Nascimento, O. R.; Horner, M.; Batista, A. A.; Inorg. Chem. 1992, 31, 4749. 
26. Enraf-Nonius, CAD-4 EXPRESS Version 5.1/1.2, Enraf-Nonius: Delft, The Netherlands, 1994.

27. Spek, A. L.; HELENA CAD-4 Data Reduction Program, University of Utrecht: The Netherlands, 1996.

28. Spek, A. L.; PLATON Molecular Geometry and Plotting Program, University of Utrecht: The Netherlands, 1997; North, A. C. T.; Phillips, D. C.; Mathews, F. S.; Acta Crystallogr. 1968, A24, 351.

29. Altomare, A.; Burla, M. C.; Camalli, M.; Cascarano, G.; Giacovazzo, C.; Guagliardi, A.; Moliterni, A.G.G.; Polidori, G.; Spagna, R.; J. Appl. Crystallogr. 1999, 32, 115.

30. Sheldrick, G.M.; SHELXL97 Program for the Refinement of Crystal Structure, University of Göttingen: Germany, 1997.

31. Solomons, T. W. G.; Organic Chemistry, John Wiley \& Sons: New York, 1996.

32. Horn, A. Jr.; Fernandes, C.; Bortoluzzi, A. J.; Vugman, N. V.; Herbst, M. H.; J. Mol. Struct. 2005, 749, 96.
33. Geary, W. J.; Coord. Chem. Rev. 1970, 5, 143.

34 Imbert, C.; Hratchian, H. P.; Lanznaster, M.; Heeg, M. J.; Hryhorczuk, L. M.; Mcgarvey, B. R.; Verani, C. N.; Inorg. Chem. 2005, 44, 7414.

35. Dietrich, M.; Münstermann, D.; Suerbaum, H.; Witzel, H.; Eur. J. Biochem. 1991, 199, 105.

36. Greenwood, N. N.; Gibb, T. C.; Mossbauer Spectroscopy, Chapman and Hall: London, 1971.

37. Kahn, O.; Molecular Magnetism, VCH Publishers: New York, 1993.

38. Gorun, S. M.; Lippard, S. J.; Inorg. Chem. 1991, 30, 1625; Werner, R.; Ostrovsky, S.; Griesar, K.; Haase, W.; Inorg. Chim. Acta 2001, 326, 78.

Received: June 13, 2006 Published on the web: November 7, 2006 